\title{
Process approach in teaching of ESL writing: Teacher's assistance and its practicality in a real classroom
}

\author{
Ilyana Jalaluddin \\ Universiti Putra Malaysia, Serdang, Selangor \\ Corresponding author: ilyana@upm.edu.my \\ DOI: https://doi.org/10.37134/jrpptte.vo19.no2.6.2019
}

Received: 8 September 2019; Accepted: 11 December 2019; Published: 11 December 2019

\begin{abstract}
Writing in a first and second language are two different contexts and involve significant different composing process. In general, most ESL students have difficulties in the rhetorical and linguistics aspects of writing because of their prior education and education backgrounds. Given the complexity of writing tasks, it is not surprising that L2 writers may experience various writing difficulties ranging from mechanical up to the content or idea development level. Although writing is teachable, the conversion of thought into written form is a difficult activity that requires organized pedagogical approaches and complementary skills. This is a case study which discusses the practices of process approach in teaching ESL writing and its practicality. The findings were based on a long-term observation and interview of three form 4 students and a teacher in Malaysia rural area school. Students' writings were analysed to show the students' development when activities based on Process approach were implemented. Findings managed to identify five different techniques used by the teacher in trying to implement process approach in writing. This process process managed to show the students the fallacy of assuming too much in writing and the need to provide more detail, or where they were being repetitious of ideas and get off the track. Changes could be seen in terms of words and elaboration in the second draft throughout the learning process until the compositions were produced.
\end{abstract}

Keywords: Process Approach, teacher's assistance, self-efficacy,Writing process

\section{INTRODUCTION}

L2 writing pedagogical practices in ESL contexts are different in many ways. In writing classroom, many researches have argued that a teacher needs to help students to develop writing skills by giving feedback or assistance in writing compositions. The connection between teacher's assistance and the students' performance plus the will to persevere in writing task somehow work like a chain as it is interconnected to one another. Fareed, Ashraf \& Bilal (2016, p.81) posited that;
...poor writing skills originate from two factors: the teacher and the learner. Teachers lack appropriate pedagogic approach to teach writing, including providing prompt and effective feedback to students, and most crucially, teachers' lack of ability to motivate students. On the other hand, students face numerous challenges: effects of L1 transfer lack of reading, motivation, and practice.

Here, it can be argued that the teacher's feedback or assistance received by the students will indirectly influence the students' confidence or self-efficacy in writing as it gives the input of how much the students have progressed so far. Uchida, Michael and Mori (2018) explained that students who more strongly endorse these beliefs of selfefficacy are better able to monitor their activities, adopt proximal goals, select well-tuned strategies, and motivate themselves. In relation to writing skills context, student will have the impression of how capable he/she is in writing as the student works on his/her composition. This in turns will affect the student's confidence to perform in his/her writing. This is because "self-efficacy affects behaviour such that a person with high self-efficacy tends to expend considerable effort when performing tasks and perseveres despite difficulty, therefore achieving good results" (Chea \& Shumow, 2014, p.254). Here, students' progress will in return give input to the teachers as it would tell the teachers to what kind and what level of assistance that the students need when completing the task (Mok, 2008). 
Obviously, teacher's assistance is important to enhance the students' skills in writing. Isaacson (2004) previously emphasized that students' achievement in writing is linked to teaching practices such as providing frequent opportunities to write and focusing on the writing process. Manuel and Carter (2016) further elaborated that "equipping students with the wide repertoire of writing capacities necessary to succeed in the world of school and work depends in large part on the pedagogical and theoretical choices of their teacher." (p.1) found that one of "the main causes responsible for this weakness in writing is classroom environment, teaching practices and lack of motivation on the part of teachers to adopt different techniques for teaching writing". Thus, it is important to investigate the role of the teacher in the writing process as well, as "the teachers who do not feel efficacious in the writing domain lack the ability to model good writing, a necessary skill in the development of the students writing" (Pajares, 2003, pp.3).

Many of the findings in L1 and L2 contexts show that teachers' interactive approaches were able to improve writings in terms of efforts, motivation to write and content of the writng (such as Onrubia \& Engel, 2012; Hassan, 2018; Padmadewi \& Artini, 2019). However, these findings are from different cultural and educational context and it cannot be generalised to the local situation as pedagogical practices are believed to be situationspecific and domain-specific, and has been found vary depending on the educational context. Since learning and acquiring language is domain-specific, studies should not simply compare the learning process, cognitive, affective or motivational characteristics of groups of students from different countries or ethnic groups and do not identify the aspect of culture. Since there is a difference in learning and beliefs across the culture, it is therefore important to explore and identify the practise of teacher's assistance in L2 writing classroom in ESL context.

\section{THEORETICAL PERSPECTIVE}

The theoretical framework that underpinned this study is Vygotsky's social-cultural theory and Bandura's sociocognitive theory. Based on the combination of these two theories, there are three important elements identified for the specific framework of this study. They are affective factor (self-efficacy), social factor (teacher) and physical factor (written work). These three components are related and affect one another as portrayed in the diagram 1. In the diagram, self-efficacy component acts as a filter which means that it indirectly affects students' performance whether in terms of behaviour (how they act) or their written product (how they perform). Meanwhile social/culture component refers to the teacher and all the activities that take place in the learning process. Teacher's element includes the assistance given and through the assistance and interaction, the students are able to gain some input that they understand so far. Based on the input they gained, the students might feel confident (high selfefficacy) to engage in the task which further improve their written work. With the confident and language that they have, the students are able to form a complete ideas (output) to be put on a paper or present it to the audiences. This element turn back to the society/culture element as the students will get feedback from the audiences and the monitoring process continues to help improve the students' output. This may affect the students' self-efficacy as feedback may affect their perception of their own skill in writing. These concepts can be illustrated in the following conceptual framework;

Figure 1 Conceptual framework of this study

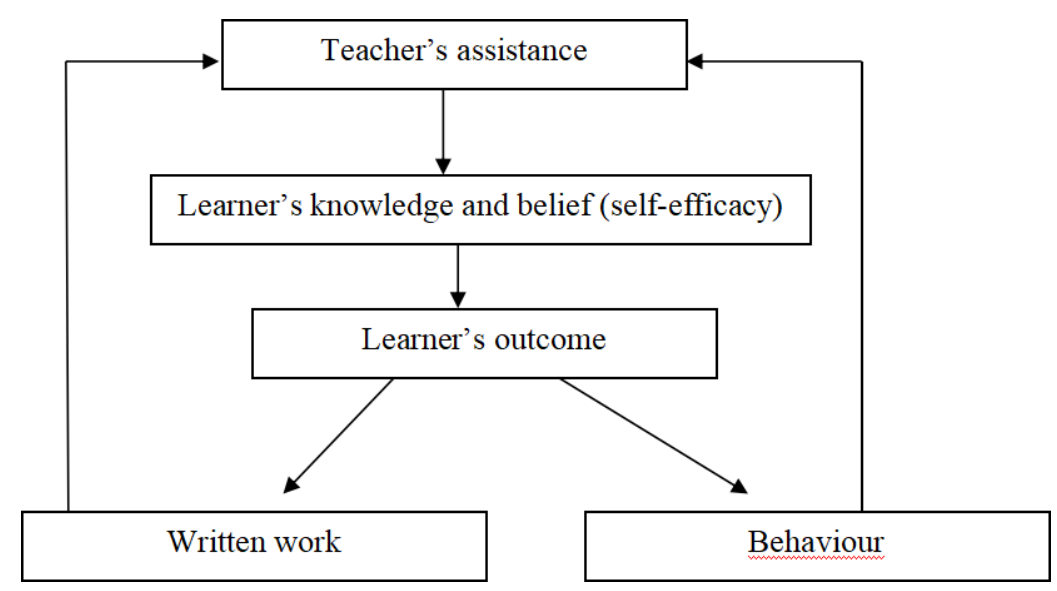


Overall, three elements have been emphasised in the conceptual framework above. Firstly, is the self-efficacy component derived from the Bandura's socio-cognitive theory. Secondly is the social/culture elements and performance element as taken from Vygotsky's socio-cultural theory plus Bandura's socio-cognitive theory as well. These elements are the base for the process of understanding teacher's assistance in developing rural students' writing skills and writing self-efficacy.

\section{Product-based versus process-based approach}

In recent years, there is an increasing emphasis on the links between the writing process and the written product (Chitravelu, 2005). Graham and Sandmel (2011) pointed out based on their meta-analysis of process writing approach that the instructional method that best situated to be implemented broadly in any effort to reform writing practices is the process approach. Here, the teachers are encouraged to guide students through planning, drafting and revising. According to Graham and Sandmel (2011), the teaching tools via process approach also able to "provide mechanisms for addressing the instructional needs of individual students and apart from that motivation for writing can be enhanced through collaboration, personal responsibility, personal attention and a positive learning environment that are stressed" (p.397). Clearly, process approach basically tries to establish a supportive environment in which students are the active writers in constructing their own writing.

This is different from product-based approach where the students receive instructions emphasising completing the assigned paragraphs and it focuses on very rigid text features of model texts. As a consequence, the process-goal students outperform product-goal students in self- efficacy, writing achievement and strategy use when writing paragraphs and displayed greater transfer to new writing tasks after six months (Zimmerman $\&$ Schunk, 2004). This is due to the fact that product approach looks at 'What is written in the text and what score can be given?' and the process approach looks at 'How is the text written and how to improve the development of the content and ideas'. As a result, students in product approach here become the operators of the learnt language structure and the teachers become the editors or proof-readers.

Specifically, the writing strategies revolve around five recursive stages that writers use in developing a written document and in each stage the teacher has an active role (refer to Figure 3). White and Arndt (1991) as cited in Harmer (2004) emphasised that these five stages are drafting, structuring (ordering information, experimenting with arrangements, etc), reviewing (checking context, connections, assessing impact, editing), focusing (making sure what the writer wants to convey is conveyed), generating ideas and evaluation (assessing the draft and/or subsequent drafts).

Figure 2 White and Arndt's process writing model

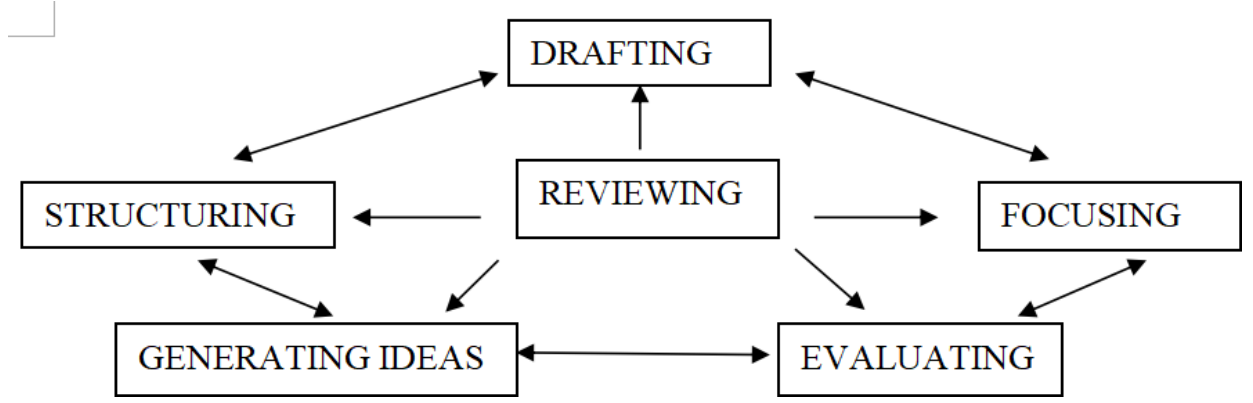

Source: Harmer (2004)

These stages as shown in Figure 3 do not take place in a fixed, linear progression but rather consist of many starts, stops, and movements back and forth across the five stages as ideas are generated and refined (Scott \& Vitale, 2003). Here, the writer usually jots down his ideas (first draft), then attempts to write his ideas in some order (second/third drafts), and finally, checks for surface correctness (spelling, punctuation, grammar). Furthermore, in every stage of the writing process, the teacher plays an important role. "In this recursive environment of process approach, interaction between the teacher and students is continuous and mutually responsive as writing is supported and monitored by the teacher" (Scott \&Vitale 2003, pp.221). According to Saidon, Said, Soh, \& Husnin (2018) the guidelines prepare by the Ministry of Education Malaysia describes the need for the process approach of writing classroom as it stipulates that teachers are expected to prepare students extensively by providing instructions, writing supports and samples of good compositions in a step-by-step manner prior to requesting students to submit the essay. Basically, the role of the teacher in the writing process can be illustrated as Figure 4 below: 
Figure 3 Teacher's role in writing process approach

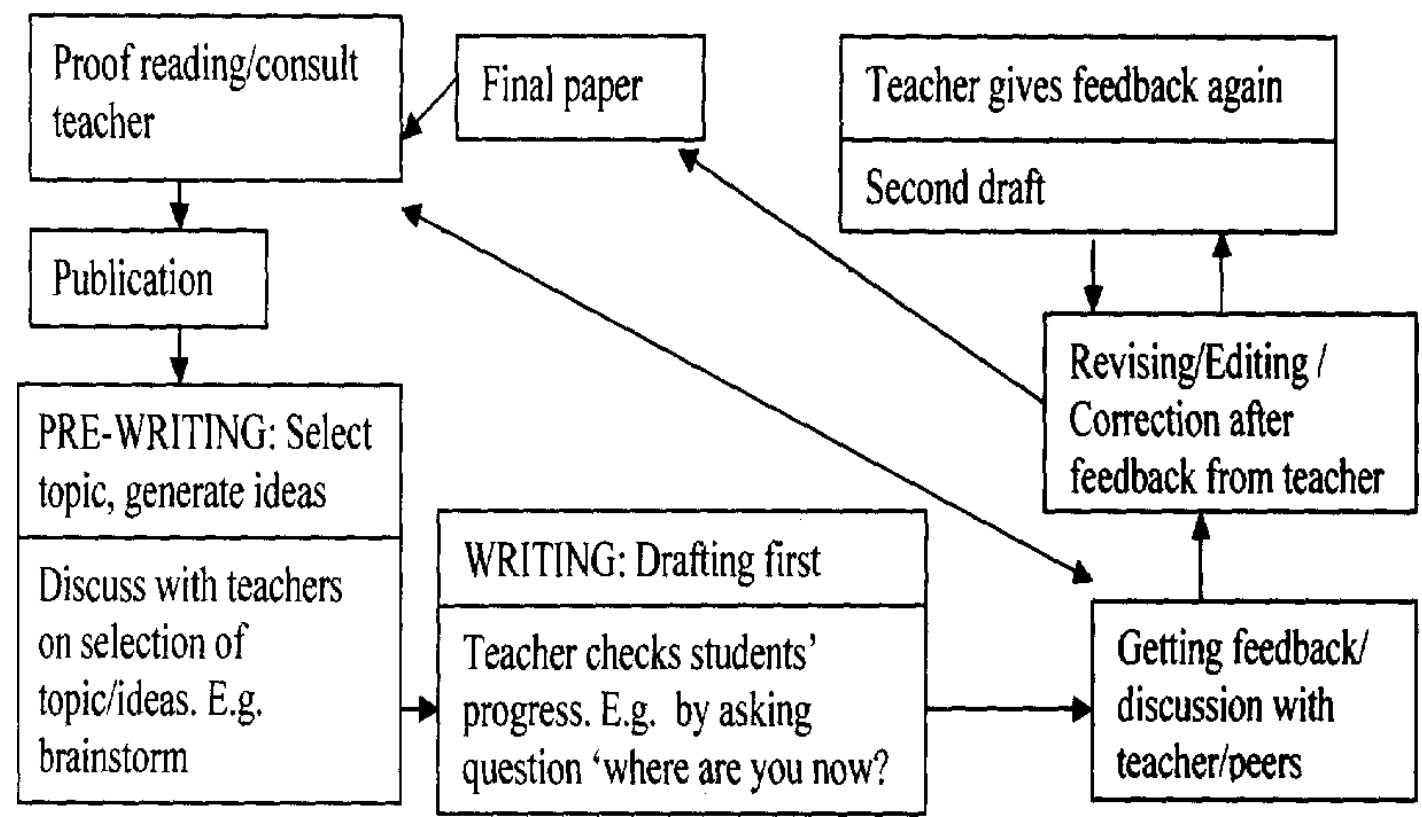

Source: Earle and Zimmerman (2002)

In sum, the process approach framework as discussed above not only shows what should take place when students are learning to write but also the importance of the process approach in writing. Based on the writing process approach, writing thus should be a process consisting of continually drafting and revising towards the finished product. This implies that teacher's assistance needs to be ongoing or continuous as it plays an important role in assisting students to grasp their writing skills and their confidence in writing. In addition, it implies that teacher's role needs to be broader where she/he also needs to create an environment in which students will want to write and learn about writing. In short, these various elements of process writing (i.e.the students' ownerships, teacher's active role, and confidence in writing) can indirectly be integrated in the view of writing as a social activity, which shows affective, as well as cognitive advantages associated with collaboration in a community of students. In other words, it entails that writing should not be seen as an isolated process but involves the community or environment of the students (i.e. teachers) in order to improve writing.

\section{Purpose of the study}

The purpose of the study is to identify teacher's assistance in writing and how it affects the students' writing skills. Specifically, this study aims to answer the following research questions;

1. How does the teacher assist the rural area learners in teaching and learning to write?

2. How does teacher's assistance affect the rural area learners' writing skills?

\section{METHODOLOGY}

\section{Research design}

This qualitative study adopted a case study approach because it allows the researcher to focus closely on the subjects and examine the issue in-depth rather than spreading the attention over a broader domain. By studying just one group of learners from one particular school where this approach was tried out (SMK Angsana - pseudonym) is to some extent a case study. Besides, one of the objectives of the research is to understand assistance provided in writing class in a natural setting and its effects on writing skills. Thus, there is a need for the researcher to be close to the participants to explain the relationship of the variables (i.e. teachers' assistance and writing skills) in details and probe deep into the issue.

This study placed a heavy emphasis on the students' writing tasks, perceptions and actions of Form Four learners and their teacher through classroom observations, and interviews with the learners and teacher. Students' written works were important to show the students' development and skills in writing. While by 
Journal of Research, Policy \& Practice of Teachers \&

Teacher Education (ISSN 2232-0458/ e-ISSN 2550-1771)

Vol. 9, No. 2, December 2019, 66-78

having classroom observation and interviews, it allowed the researcher to assess the participants' unobservable (such as feelings) and observable behaviour which were used in the language tasks. Classroom observation was used in this study to further explain teacher's assistance in the writing classroom. Meanwhile, the interviews with the learners and teacher were used to describe the rationale of support given.

\section{Context and Participant}

For the purpose of this study, a rural co-educational government secondary school in Perak was selected. SMK Angsana is one of the biggest rural secondary schools in Hilir Perak. It is situated outside the District Council area, which is about 22 kilometres from the nearest town, Teluk Intan. For the purpose of the study, the researcher was given one Form Four class by the principle of the school. The researcher then chose to use purposive sampling where three respondents out of 26 students from the Form Four class were chosen for the focus of the study. These were the students who obtained the lowest, average and the highest scores in writing. Here, the researcher had chosen to work with a small sample of subjects because it helped the researcher to study the subjects in-depth. It also helped the researcher to give a detailed description of teacher's assistance, allowed an in-depth analysis of the learners' work and changes in writing skills. These three students and teacher were observed for six months and seven essays were managed to be produced for the study.

\section{Research process}

A total of seven essays were written during this data collection period. These essays were evaluated based on the marking scheme by Malaysian Examination Syndicate. There are two categories namely directed and continuous writing. This study focused on both categoris to get a more holistic writing report for each student. However, only four essays will be discussed in detail in this paper namely:

\section{Essay 1: How to score As in the SPM examination \\ Essay 2: My father \\ Essay 3: Footprint \\ Essay 4: Writing narrative essay "It was midnight..."}

Two drafts were written for each essay. As such, the process of producing one essay, took more than one lesson. In general, the writing process of each essay took more than a double period (1 hour) and the lesson continued the week after that which was also a double period class. The following sections illustrate the overall process of writing the following four essays.

In the first week of the lesson, the teacher's focus was more on the students' content. At this stage, she preferred to ask questions first to elicit more ideas from the students rather than her giving all the ideas to the students. By questioning and encouraging the students to talk about their writing, the teacher came to realise what needed to be done to help them, and it also helped the students to become their own resources rather than relying on others to develop and improve their writing. This finding also reflects the new framework by Flower and Hayes (1990) which emphasise on medium (tool) such as guided questions and comments as part of the composing process. It was like a brainstorming process where the teacher probed students with questions and the students were able to elaborate more on the ideas by answering the questions. This portrays the prewriting stage of the writing process as suggested by Karatay (2011).

After the students finished listing their rough ideas, the teacher would give 30 to 40 minutes for them to write their first draft and submitted it. They were allowed to discuss with their peers as well to develop their ideas. This portrays more of the writing stage in a writing process as pointed out by Siti Hamim Stapa (1998) who terms this stage as the act of producing the first draft or drafting. After marking and checking the students' first drafts, the teacher would return them a week later which would be the second week of the lesson. Upon receiving their first draft, the teacher assisted the students in three ways: giving clues, comments, and suggestions. At this stage as well, the teacher started to focus on the language aspect. The teacher distributed the handout and asked the students to identify the language errors in each sentence. Based on the students' responses, the teacher would comment their sentences. This 'sentence surgery' process normally took about 30 minutes. In short, this exercise is the process of editing and revising the students' sentences in the first draft. Thus, this portrays more of the writing stage in a process-based approach. As Earl and Zimmerman (2003) and Karatay (2011) pointed out that the writing stage of a writing process includes the editing and revising stages.

After the sentence surgery exercise, the students would write their second draft for about 30 to 35 minutes. While they were working on their second draft either in group or individually, the teacher monitored their progress closely. The teacher would sit with the weak students and observed how they wrote their second draft. At this stage, the teacher focused on their vocabulary and content development. Through the face-to-face discussion, the students were able to ask questions regarding the written comments that they received in their first draft. The teacher then explained and gave suggestions on how to rectify the errors. This portrayed the writing stage where the students were still in the process of revising and editing their first draft and trying to produce their second draft based on the 
comments they received in the first draft.

After the second draft was completed, the students then submitted it to the teacher, and she would provide the marks or grade. This portrayed more of the post-writing stage where the writers despatched their writing to the readers and from here, they received the reader's responses. Overall, throughout the process, the students were able to produce two drafts after going through the process of brainstorming, drafting, editing and revising before publishing it for the teacher to read. This depicted the writing process approach as suggested by Duke (1983), Siti Hamim Stapa (1998), Earl and Zimmerman (2003) and Karatay (2011). Throughout the process as well, there were five main assistances provided by the teacher that can be identified - asking questions, giving comments, giving suggestions, clues as well as providing individual discussions. Here, teacher's assistance in this study can be briefly summarised and presented in Figure 5 which was adapted from a diagram by Earle and Zimmerman (2002).

Figure 4 The writing process in this study

\begin{tabular}{|l|l|}
\hline $\begin{array}{l}\text { Teacher returned draft } \\
\text { - Teacher gave written comments }\end{array}$ & $\begin{array}{l}\text { Learners drafting first draft } \\
\text { - Individual or group work } \\
\text { - Teacher checked \& asked questions to } \\
\text { help expand the learners' ideas }\end{array}$ \\
\hline \begin{tabular}{|l|l|}
\hline Learners submitted second draft \\
- In class or at home \\
- Teacher sat with the weak learners and \\
guided on how to write \\
- Teacher explained to the class \\
especially grammar rules \\
- Teacher gave verbal comments \& \\
clues
\end{tabular} & $\begin{array}{l}\text { Learners presented to the class or } \\
\text { submitted to the teacher } \\
\text { - Teacher gave written comments their } \\
\text { essay books and grades/marks }\end{array}$ \\
\hline
\end{tabular}

Based on Figure 5 above, it shows that the teacher created a prototypical element of writing process which involved drafting, editing and rewriting. In doing so, the teacher was able to question, and give comments to get clarification and elaboration from the students systematically and indirectly help to improve their draft consequently. In sum, with this intervention, it is thus important to see how teacher's assistance affects the students' writing skills.

\section{Findings and discussions}

It was observed that the teacher assisted the students' writing by asking questions, giving comments, and individual guidance at the pre-writing and writing stages which depicted a more assisted learning.

\section{Prompting questions}

In the class, the teacher probed the students with a lot of questions during the writing activities. There were two purposes of questioning the students during the writing activities. Firstly, the teacher aimed to help them develop their ideas during the pre-writing stage without focusing on the language aspect yet. It was observed that the teacher used Microsoft Words program to show the idea development by typing the students' ideas which were displayed on the whiteboard. She then gave the title of the essay and discussed with the class for the idea elaboration. In other words, she did not directly teach the format of the essay but develop the ideas first through questioning technique. She asked each one of them to contribute ideas and only commented when they did not give suitable ideas for the topic. Apart from providing comments and throwing questions, the teacher also probed the students to correct each other's ideas. For instance, the teacher asked Haslina to suggest an idea for an introduction and Haslina suggested "This can improve and achieve our lesson during study" (classroom observation). Based on Haslina's response, the teacher commented that she had not elaborated it properly. Farah then suggested phrase "After plan it..." but she stopped when the teacher commented that the phrase "After plan it..." did not fit into the paragraph. Other student then suggested to replace Farah and Haslina's suggestions with "We must plan on how to 
achieve our goal". Once the teacher agreed, she typed the sentence on the screen for everyone to see. The process continued until one essay managed to be produced through the discussion. In short, the teacher assisted the students during the pre-writing stage in developing their ideas via probing questions in order to get feedback or ideas. To summarise, the students were asked to contribute ideas and based on the ideas given, the teacher then probed with questions so that the ideas were developed properly. When asked during the interview, the teacher pointed out that "[she] wanted them to think of the words [and] to eventually find them out even though [she] could easily give out the words..." (Interview).

In the way, the supportive scaffolding is indirectly portrayed through this assistance where the teacher consistently solicited information from the students via questions and finally led to the dialogic conversation among the students. This led the students to infer what the activity means in the setting, how to go about implementing it and, eventually, used the tools of the instructional conversation as their own. There was a transfer of responsibility from the adult to the students. This was because the students independently tried to solve the written task on their own based on the knowledge they gained from the dialogic discussion. In addition, believing they are "good students" and that they should be encouraged to think rather than being "spoon fed" also contributed to the transfer of the adult knowledge to the students. Therefore, the goal of the teacher when probing students with the questions was for the students to become independent and self-regulate and problem solvers. This is an important aspect of providing scaffoldings to the students in an educational setting. This is because an important aspect of scaffolding instructions is that the scaffolds are temporary. As the students' abilities increase, the scaffolding provided by the more knowledgeable other is progressively withdrawn (Mcleod, 2012).

Overall, the teacher used the question technique as a mean to assist the students to develop their ideas in writing and to rectify their language errors in their drafts. The students had to put on their thinking caps to get the correct sentences by answering the teacher's questions and using the given clues. In other words, the teacher acted as the facilitator throughout the writing process where she helped the students overcome the difficulty to begin writing without assuming total control over the students' learning process. Thus, it can be seen that participation among students was encouraged here by eliciting their reasons for supporting their statements or position. Besides that, the teacher's questions such as "what do you mean" and "what happened next" also encouraged a more complex expression by requiring the students to expand their ideas in a more meaningful way. Both styles indicated an invitation to participate in a higher-level conversation and thinking. In the way, this is parallel to Bloom's Taxonomy where students were guided with questions from simple to more complex thinking. In other words, the students were encouraged to evaluate their writing after they created it. There was an exploratory talk here where the students tried to explore and clarify their ambiguous ideas until intersubjectivity was achieved. This was achieved through the teacher's questions and comments which guided them to analyse more closely of their writing that was within their ZPD and finally led to their understanding. Once the information was understood, the students tried to apply in their second draft independently. This relates directly to Vygotsky's notion of work on the ZPD (Zone of Proximal Development) that is the time between when the students able to do a task independently and with the assistance of an expert individual.

\section{Giving comments for further improvement}

Apart from asking questions, the writing processes of the four essays showed that the teacher also gave comments after the students finished their drafts. Here, it was observed that the teacher gave general and specific comments as a guidance for the students to focus on specific area in their writing. Firstly, the teacher pointed out the errors in general and also explained the reasons why the essay was wrong. For example, the teacher gave many general comments after the students had presented their essay entitled "Footprint" (Classroom observation). Based on the students' presentations, the teacher pointed out that most of their storyline was illogical and it was not critical enough. This can be considered as general comments as the teacher did not specifically pointed out in what way the storyline was not critical enough. The teacher then made comparison between all of the stories written by the students and pointed out generally the strengths and weaknesses of their essays. For example, she commented that the students' stories consisted of too many language errors such as on sentence structures and tenses (Classroom observation). In addition, the teachers also mentioned the stories on rabbit and kitten were interesting and logic but stories on the UFO, dwarfs and aliens were fictional (Classroom observation). This showed a more general comment where the teacher used the students' essays as examples to give the overall picture of their writing.

In terms of specific comments, the teacher specifically pointed out the errors contained in the students' essay especially in terms of the language aspect. For instance, the teacher went to Farid's desk and commented about the use of apostrophe "s" in his sentences (Classroom observation). The teacher pointed out that not all words which end with "s" have apostrophes. She then asked him "what do you mean when you use the apostrophe 's"?". Farid was quiet. The teacher then gave an example "This is Amin's bicycle" and pointed out that "the apostrophe in this sentence is used to show that the bicycle belongs to whom and we don't put apostrophe to the verb "is"'. Farid then erased his apostrophe and read again his essay to find other apostrophes. In another instance, the teacher gave specific comments when the students did many similar language errors in their writing. Similarly, the teacher pointed out specifically what type of mistakes that the students did in their writing. For example, the teacher focused more on tenses and explained to the class how to use past or present tense correctly in their writing 
(Classroom observation). Apart from looking at the students' tenses, the teacher also commented that the use of pronoun "he" or "they" needed to be consistent to ensure coherency in writing. In short, the examples from the classroom observation showed that the teacher did not just specify the errors that the students made in their writing, but she also illustrated on how to write correctly by showing examples.

Nevertheless, when the students were unable to rectify their errors, the teacher then gave specific comments. Here, the teacher asked the students to explain first what they understood so far and when they could not respond. The teacher commented specifically why a particular sentence was wrong. It was observed that the teacher explained how the sentence should be formed. For instance, Aishah was uncertain on how to write a poem about examination (Classroom observation). The teacher assisted her by explaining the appropriateness of the words that she used such as "I think" which sound unconvincing or "like you are going to". Besides commenting on the words she used, the teacher also commented on her spelling of "enemy" which should be "enormous". From the teacher's comments, Aishah was able to produce a word for her sentence "exam like api yang besar" [an examination is like an enourmous fire] (Classroom observation). Even though the answer was in Malay language, it depicted that teacher's comment on the language guided Aishah in making comparison.

When asked during the interview, the teacher admitted that "[she] spent a lot of time with Aishah's group because they were doing something new and different to them" (Interview). Since writing poem was new to the students, the teacher pointed out that "[she] felt that assistance in constructing the sentences was important in writing the poem" (Interview). Thus, she focused on how to write the poem by pointing out the choices of words that the students could use and what kind of sentence structures that they could use for a poem (Classroom observation). Overall, the classroom observation showed that the teacher gave two different comments which were specific and general comments to assist the students in the writing process. The teacher gave specific comments when the students made a lot of language errors such as tenses, spelling and choice of words. However, when the students presented a vague idea in their writing or unable to elaborate the ideas clearly, the teacher would give general comments as a guidance for them to focus. She would mention how the students developed the ideas and how to further improve the essay.

In conclusion, the teacher's act of commenting the students' writing portrayed that she acted as the mediator in the writing process. This is because it was observed that she occasionally guided the students' writing through interaction and feedback in the form of general or specific comments. The interaction and feedback provided by the teacher in this study did not just guide a particular student but also helped the other students since the interaction normally led to class discussions involving all students. Thus, the connection can be represented as two related chains with the teacher's interaction as the intervention in the students' writing process:

Figure 5 The teacher's scaffolding within the students' development in writing

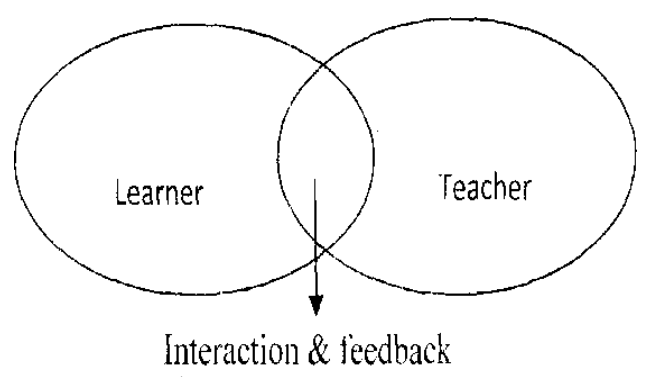

Figure 6 showed that the teacher as the mediator in the writing process constantly monitored the students' progress. When errors were detected in the students' writing, the teacher gave her feedback and discussed further with the class. This is why the two chains above overlapped because the teacher's assistance intervened and at the same time encouraged social factors such as other students to respond as well. This intervention is also evidence in next section where the teacher gave suggestions or answers for correction.

\section{Giving suggestions or answers for correction}

Based on the four essay writing processes, it was observed that the teacher also gave suggestions either in the written form or verbally to help the students improve their writing. In the written form, the teacher specifically listed the errors in the students' essay and wrote down the suggestions for each error. For instance, when the students were required to write a narrative essay beginning with "It was midnight...", the teacher guided them closely by giving written suggestions and comments (Classroom observation). After they had written their draft, the teacher checked and returned the draft to them. Here, the teacher gave very detail comments by listing each error such as below: 
I decided to find my aunt's house by myself walking. Maybe only three (11) kilometer from here. (12) Why this bad thing happen (13) to me? What my aunt's fault (14)?I get troubles because of that.

Based on the example above, it shows that the teacher underlined the sentences that contained errors and labelled them with numbers in the ascending order such as 11,12, 13, and 14. Based on the numbers, the teacher then commented and gave suggestions on how to correct each numbered error. For example, based on the numbered errors above, the teacher wrote the suggestions in the students' book as indicated below:

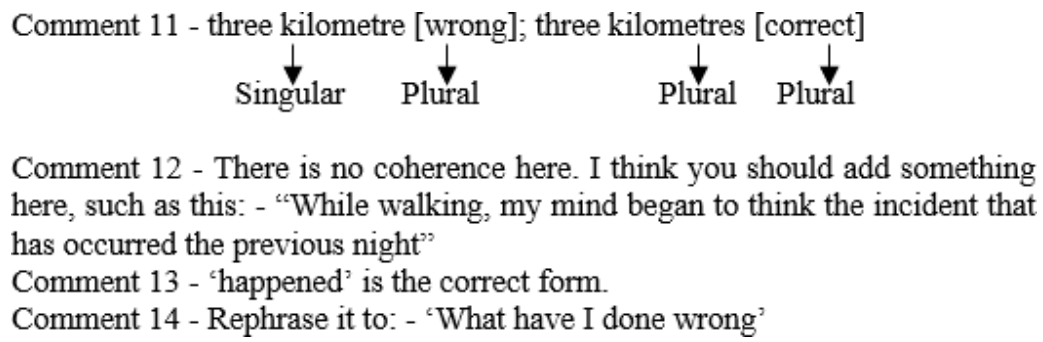

Comment 12 - There is no coherence here. I think you should add something here, such as this: - "While walking, my mind began to think the incident that has occurred the previous night" Comment 13 - 'happened' is the correct form.

Comment 14 - Rephrase it to: - 'What have I done wrong'

Based on the excerpt above, it showed that the teacher gave very specific written suggestions to help the students further improved their writing. The teacher also wrote the rationale behind the suggestions given. This was also supported by Farah who pointed out that the "teacher was very hardworking and willing to list all the mistakes although [she] had so many mistakes" (Interview). "This had helped [her] learn more about [her] weaknesses in writing" (Interview).

\section{Giving clues}

Apart from giving suggestions and comments, the teacher also assisted the students to understand the context by giving clues. She gave clues in two different ways which were examples related to the students' real life and secondly, by translating English words to Malay. Firstly, it was observed that the teacher used both languages; Malay and English when the students could not guess the right words or suitable sentences for their essays after several attempts. For example, the teacher pointed out that the phrase "Hockey's stick" was wrong and kept probing questions "why the phrase was wrong" (Classroom observation). The students gave up by saying tak tahu (do not know). Since the students were unable to detect and understand why the sentence was wrong, the teacher translated the phrase to Malay language to help them understand. She mentioned saya punya hoki punya hoki to indicate that the phrase "my hockey's stick" was wrong. Based on the teacher's example, the students then able to give responses. Fayyad responded "Hockey stick" which showed he deleted the apostrophe and "s". Similarly, the teacher gave clues in Malay language when the students could not guess the meaning of "grumble" (Classroom observation).

In short, the observation data showed that by providing clues in Malay, the students were able to grasp the meaning better. Thus, they were clear on what they needed to do in their writing as indicated by Haslina that "she knew what to write as she understood it more [and] knew what to do especially in writing" (Interview). Besides translating certain words to Malay, the teacher also gave examples that were related to the students' real-life situation as clues. For example, in one of the lessons the students were required to write a story based on the poem "IF" by Rudyard Kipling that they had learned (Classroom observation). In order to help them understand the poem, the teacher provided a lot of instances that related to the students' real life situation. In one instance, she read aloud the line "If neither foes nor loving friends can hurt you" and asked the students the meaning of the word "foe". Noran responded "enemy" and the teacher agreed. She then asked the students to form their own sentences, but they just remained quiet. Thus the teacher asked the students "How they treat their neighbour, whether they give food to their neighbour?". The boys responded "Yes". The teacher then asked them again "If someone with a big car comes to your house, what do you serve him compare to someone cycling a bicycle coming to your house?". The class then responded "same food" and Fayyad further elaborated "we must be fair". Based on the students" responses, the teacher then asked them to form a sentence. Noran responded "We should be fair to everyone/be just to everyone" and the teacher agreed.

Apart from giving examples, the teacher also told stories that happen in everyday life. For instance, the teacher told the class about her experience of going to a friend's house to illustrate the meaning for "If you can talk with crowds and keep your virtue or walk with kings - nor lose the common touch". The teacher's story began with her friend inviting her to the house and said minta maaf, air kosong je, kami tak beli itik (sorry, only plain water, we don't buy ducks). The teacher then asked the students the connection between the itik (duck) and air (water) in her context of visiting a friend. The students admitted that they could not see the connection. The teacher then asked "What if itik gets into water?" and explained that the water will change colour because of the mud and dirt. Thus, if a person says tak beli itik, it means they cannot afford to buy condensed milk to make teh susu. The teacher informed the students that if she went to anyone house, she did not mind being served with plain water only. Noran 
then responded "We should be humble and don't forget ourselves". In short, these examples were used by the teacher to illustrate the meaning of being humble as portrayed in the poem. By giving examples related to everyday life situations, the teacher was able to assist the students to understand the poem better and finally the students were able to form a sentence based on the poem as indicated by Haslina in the interview. She said that "[she] was able to write the story more afterwards as [she] had the vocabulary to use in [her] writing" (Interview). This was because "[she] understood the poem after the teacher related the poem to a story in real life situation (Interview).

Overall, the teacher used the scaffolding strategy which was cues in the native language that is Malay language or stories related to everyday life. Based on these cues, the students then able to relate to their own learning and finally expressed their ideas clearer. This indirectly portrayed Vygotsky's (1978) notion that the cultural aspect is important in developing the content of students' intellectual thinking. In this study, "cultural" can be derived from the Malay language and daily experiences provided by the teacher. In other words, they triggered ideas for the students of what to write for their writing. Though the clues did not help in terms of grammatical structure, they helped the students to expand their ideas in their writing. In addition, they helped the students to come up with better choices of words to convey their intention.

\section{Giving individual guidance or individual face-to-face discussion}

Finally, the teacher also provided personal guidance to certain students who were very weak in writing. It was observed that she sat with the particular students and observed them while they were correcting their writing. While they were correcting their writing, the teacher pointed out the mistakes in their writing and asked them to try correcting the mistakes. Based on the corrections, she then asked the students why they changed the errors that way. Apart from pointing out the errors, the teacher also discussed and answered questions posed by the students regarding the comments she gave for their writing. This as further supported by Haslina who "felt more comfortable when the teacher discussed with [her] individually" (Interview). Obviously, individual discussions evoked students' interest to engage more in the writing process. This could be further portrayed in the lesson where the teacher sat down with Farah while she was correcting her work (Classroom observation).

While the teacher was observing her, Farah asked the teacher why she circled her word "weird". The teacher explained that the sentence was incomplete. Teacher told Farah that she used the word "weird" without modifying a noun. She then explained further that "weird" is an adjective, so there should be a noun after that. Farah then responded that she actually meant janggut but did not know the word in English. Based on Farah's response, the teacher then asked whether she meant "the long bushy" or "the short one" and Farah responded "janggut short one". From here, the teacher then opened to the class to guess the word "short janggut" in English, but no one knew the word in English. The teacher then gave a clue that the word starts with the letter "g" but nobody could give the answer. The teacher finally gave the answer "goatee". This observation data showed that the teacher was able to give detail explanation to the students when she had an individual face-face discussion. In addition, the students were able to ask any unclear ideas regarding their writing during the individual discussion. When asked during the interview, the teacher explained that "the main reason why [she] really spent time and focused on individual students instead of one class in general was that [she] wanted the students to see how they should construct the sentences correctly" (Interview). By focusing individually, she would be able to see how the students rewrote the sentences or she reconstructed for them.

Besides individual helps, the teacher also focused on those who attempted a new style of writing. For example, the teacher spent a lot of times with Aishah's group when they were writing their first draft (Classroom observation). When asked during the interview, the teacher admitted that "[she] spent most of the time with Aishah's group and guided them closely during the writing process" (Interview). This was due to the group's first attempt to write a poem rather than a normal composition. Aishah's group decided to write a poem compared to other groups in the class who decided to write an essay for the title "examination". Nevertheless, Aishah's group struggled as they had limited vocabulary and was not familiar with poem writing (Classroom observation). The teacher thus sat with the group and guided them by giving advises. The teacher prompted the group with the question of "What do you feel about examination" to help them elaborate their ideas more. While the group was trying to elaborate ideas based on the teacher's question, she observed and pointed out the wrong words used by them. She commented that the phrase "I think..." was unsuitable because it sounded not convincing. The teacher also corrected their spelling for "fear" (Classroom observation).

Overall, the teacher commented that they had the idea but they made many grammar mistakes especially on the articles "a", "an", and "the". Apart from the suggestions from the teacher, Aishah also had the opportunity to ask help from the teacher during the individual discussion to translate some Malay language words to English language. For instance, she asked the word api besar and the teacher responded, "big fire la" (Classroom observation). Based on the examples, the teacher clearly had assisted Aishah's group by focusing more on how to form sentences rather than only the grammatical aspects. By having individual discussions, the students also could ask any unclear ideas privately rather than speaking in front of the class which would be daunting to some. The teacher's focus was also not diverged where she guided closely particular students throughout the process of writing.

This implies that the interaction between the teacher and students was important in completing the writing 
tasks. It shows that writing actually involves communication and therefore teachers should encourage joint activities in the writing classroom. With this in mind, writing activities therefore should be geared towards the conversational model. The conversational model promotes active dialogues which tap into the students' dormant knowledge and consequently sharpen their writing skills. Nevertheless, different writers approach writing tasks differently; thus, determining the level of assistance in teaching is important. Some writers may need more assistance than the others. Therefore, working in groups as portrayed in this study maybe practical as it allowed the students to interact and discuss at various levels and among mixed ability group members. In short, the five assistances discussed above indirectly showed the important role played by the teacher.

\section{CONCLUSIONS AND RECOMMENDATIONS}

This study focused on rural area students' learning process by providing information on the types of assistance provided by the teacher and how teacher's assistance affects their skills in writing in the English language. It has been well established in the L1 context that a positive relationship exists between students' perception of their ability and their academic performance (such as Pajares \& Johnson, 1995; Linnenbrink \& Pintrich, 2003; Ergul, 2004; Pajares, 2006; Schunk \& Zimmerman, 2007). However, there is no documented record or study on one important element that is the teacher. This study looked into the effect of teacher's assistance on students' writing skills in a Malaysian context. It will be useful to know teachers' contribution in the L2 setting where students' language and vocabulary are limited compared to the L1 setting where language command is better (Harmer, 2000). According to Jun Zhao (2017, p.48), "many of the problems experienced by L2 writers are due to their "insufficient control of the language, muddy thinking, inexperience with writing in general and with scholarly genre in particular". Therefore, the findings of this study will be a significant contribution to any educational research in Malaysia as there has been no similar study conducted in the local context.

Despite the benefits in this study, there are several issues that can be looked further to improve other studies in the future. Firstly, this research focused on science stream students in a specific school in Perak. The students were considered smart students with good discipline record in the school studied. This has limited the researcher's finding to only this group of students whom have a good academic achievement. The research did not study students with poor academic achievement. Besides that, the study was conducted with a small number of participants. After the Science stream students answered the questionnaire, three participants were selected. Therefore, the results and conclusions underlying the research may be only the representative of this type of students and do not entirely apply to all students or population.

Finally, this research also focused on one factor that is teacher's assistance in developing the rural students' writing skills and writing self-efficacy. This is due to the reason that assistance is necessary in the process of writing. Though there were many other variables which may also affect the students' writing skills and writing self-efficacy such as the students' language competence, access to writing tools outside classroom, and help from parents or siblings, these have not been studied in this research. Thus, these have become the limitation of this study where confounding variables were not being studied as well in this research. 


\section{REFERENCES}

Annamalai, N. (2016). Exploring the writing approaches in the facebook environment. Teaching English with Technology, 16(1), 71-87.

Bandura, A. (1997). Self-efficacy: The exercise of control. New York: W.H. Freeman \& Company.

Bhela, B. (1999). Native language interference in learning a second language: Exploratory case studies of native language interference with target language usage. International Education Journal, 1(1), 22-31.

Boud, D. (2001). Peer learning in higher education: Learning from and with each other. London: Kogan Page.

Carter, D. (2016). Teaching Writing in Secondary English: Practical Approaches to Building Confidence, Enjoyment and Achievement. Retrieved from https://cpl.asn.au/journal/semester-1-2016/teaching-writing-in-secondary-englishpractical-approaches-to-building.

Chea, S., \& Shumow, L. (2014). The relationship among writing self-efficacy, writing goal orientation and writing achievement. Language Education in Asia, 5(2), 253-269.

Chitravelu, N., Sithamparam, S. \& Teh Soo Choon (2005). ELT methodology: principles and practice. Shah Alam: Penerbit Fajar Bakti Sdn.Bhd.

Duke, C.R. (1983). Writing through sequence: A process approach. Boston: Little, Brown and Company. Earl, C.B \& Zimmerman, C. (2003). The reading/writing connection. New York: Longman

Eggleston, B. (2017). Relationship between writing self-efficacy and writing fluency in a performance feedback intervention. (Master Thesis, Syracuse University, New York). Retrieved from https://surface.syr.edu/thesis/131

Ergul, H. (2004). Relationship between learner characteristics and academic achievement in distance education and application on learners of Anadolu University. Turkish Online Journal of Distance Education, 5(2), 1-10.

Fareed, M., Ashraf, A. \& Bilal, M. (2016). ESL learners' writing skills: Problems, factors and suggestions. Journal of Education and Social Sciences, 4(2), 81-92.

Ghazali, N., \& Che Omar, M. (2019, March). Does teachers' knowledge, skill and self-efficacy are important in the Implementation of English Literacy. Paper presented at the International Conference on Islam and Global Issues (iCIGI), Universiti Teknologi Mara (UiTM), Cawangan Kelantan.

Graham, S., \& Sandmel, K. (2011). The process writing approach: A meta-analysis. The Journal of Educational Research, 104, 396-407.

Harmer, J. (2004). The practice of English language teaching (Third Edition). England: Pearson Education Limited. Hartman, H. (2002). Scaffolding \& cooperative learning: Human learning and instruction. New York: City College of

City University of New York.

Hasan, M. (2018). Impact of motivational scaffolding on the acquisition of writing skills in L2 situation. International Journal of Humanities and Social Science Invention (IJHSSI), 7(12), 39-45.

Hidi, S., \& Boscolo, P. (2008). Motivation and writing. In Charles MacArthur, Steve Graham, and Jill Fitzgerald (eds.).

Handbook of writing research, pp144-157. New York: The Guilford Press.

Isaacson, S. (2004). Instruction that helps learners meet state standards in writing. Exceptionality, 12(1), 39-54.

Jarvela, S. (2001). Shifting research on motivation and cognition to an integrated approach on learning and motivation in context. In Simone Volet \& Sanna Jarvela (eds.). Advances in learning and instruction series: Motivation in learning contexts: Theoretical advances and methodological implications (pp. 3-16). New York: Emerald Group Publishing.

Jun Zhao (2017). Native speaker advantage in academic writing? Conjunctive realizations in EAP writing by four groups of writers. Ampersand, 4, 47-5.

Karatay, H. (2011). The effect of 4+1 planned writing and evaluation model to develop the attitudes of preservice teachers as to written expression and their writing skills. Turkish Studies, 6(3),1029-1047.

Karim, K., \& Nassaji, H. (2013). First language transfer in second language writing: An examination of current research.

Iranian Journal of Language Teaching Research, 1(1), 117-134.

Kucer, S.B. (2005). A conceptual base for teaching reading and writing in school settings. Mahwah, New Jersey: Lawrence Erlbaum Associates.

Linnenbrink, E.A., \& Pintrich, P.R. (2003). The role of self-efficacy beliefs in learner engagement and learning in the classroom. Reading and Writing Quarterly, 19, 119-137.

Lockhart, C. \& Ng, P. (1995). Analysing talk in ESL peer response groups: Stances, functions and contents. Language Learning, 45(4), 606-655.

Marchisan, M.L., \& Alber, S.R. (2001). The write way tips for teaching the writing process to resistant writers. Intervention in School \& Clinic, 36(3), 154-163.

McLeod, S. (2018). The Zone of Proximal Development and Scaffolding. Retrieved from http://www.simplypsychology.org/Zone-of-Proximal-Development.html

Mengjie Wei (2017). Strategies for first-year University ESL students to improve essay writing skills. (Master Thesis, The University of San Francisco USF Scholarship: a digital @ Gleeson Library GEschke Center). Retrieved from https://repository.usfca.edu/cgi/viewcontent.cgi?article=1558\&context=capstone

Ministry of Education, Malaysia (1991). Process writing. English Language Teaching Journal,Compendium, 3, 1-9. Mok, S.S. (2008). Educational psychology \& pedagogy: Learner and learning environment. Selangor: Penerbitan

Multimedia Sdn. Bhd.

Onrubia, J., \& Engel, A. (2012). The Role of Teacher assistance on the effects of a macro-script in collaborative writing tasks. International Journal of Computer-Supported Collaborative Learning, 7(1), 161-186. 
Journal of Research, Policy \& Practice of Teachers \&

Teacher Education (ISSN 2232-0458/ e-ISSN 2550-1771)

Vol. 9, No. 2, December 2019, 66-78

Padmadewi, N.N., \& Artini, L.P. (2019). Using scaffolding strategies in teaching writing for improving student literacy in primary school advances in social science. Education and Humanities Research, 178, 156-160.

Pajares, F., \& Valiante, P. (2008). Self-efficacy beliefs and motivation in writing development. In Macarthur, C.A, Graham, S., Fitzgerald, J. (ed.). Handbook of writing research (pp.158-170). New York: Guilford Press.

Pajares, F., \& Johnson, M. J. (1995, April). The role of self-efficacy beliefs in the writing performance of entering high school learners: A path analysis. Paper presented at the meeting of the American Educational Research Association, San Francisco.

Pajares, F. (2003). Self-efficacy beliefs, motivations, and achievement in writing: A review of the literature. Reading and Writing Quarterly, 19, 139-158.

Pajares, F. (2006). Self-efficacy beliefs of adolescence. Greenwich: Information Age.

Rahil Mahyuddin, Habibah Elias, Loh Sau Cheong, Muhd Fauzi Muhamad, Nooreen Noordin \& Maria Chong Abdullah. (2006). The relationship between learners' self-efficacy and their English language achievement. Jurnal Pendidik dan Pendidikan, 21, 61-71.

Raymond, E. (2000). Cognitive characteristics: Learners with mild disabilities. Needham Heights, MA: Allyn \& Bacon, A Pearson Education Company.

Saidon, M. A., Said, N. E. M., Soh, T. M. T., \& Husnin, H. (2018). ESL students' perception of teacher's written feedback

practice in Malaysian classrooms. Creative Education, 9, 2300-2310.

Sarikas, C. (2018). Vygostky Scaffolding: What is it and how to use it? Retrieved from https://blog.prepscholar.com/vygotskyscaffolding-zone-of-proximal-development

Schunk, D.H., \& Zimmerman, B.J. (2007). Influencing children's self-efficacy and self-regulation of reading and writing through modelling. Reading and Writing Quarterly, 23, 2-25.

Scott, B.J., \& Vitale, M.R. (2003). Teaching the writing process to learners with LD. Intervention in School \& Clinic, 38(4), 220-226.

Scott, B.J., \& Vitale, M.R. (2003). Teaching the writing process to learners with LD. Intervention in School \& Clinic, 38(4), 220-226.

Siti Hamim Stapa. (1998). The process approach to ESL writing. UKM Bangi: Faculty of Language Studies, Universiti Kebangsaan Malaysia.

Smith, J. (1997). How people learn to write. New Zealand: Longman.

Uchida, A., Michael, R.B., \& Mori, K. (2018). An Induced Successful Performance Enhances Student Self-efficacy and Boosts Academic Achievement. AERA Open, 4(4), 1-9.

Van Der Stuyf (2002). Adolescent learning and development course: Scaffolding as a teaching strategy. Retrieved from http:/condor.admin.ccny.cuny.edu/ group4/ Van\%20Der\%20Stuyf/Van\%20Der\%20Stuyf\%20Paper.doc

Vaus, D.A. (2001). Research design in social research. London: Sage Publication Ltd. Vygotsky, L.S. (1978). Mind in society. Cambridge, MA: Harvard University Press.

Zimmerman, B.J., \& Schunk, D.H. (2004). Self-regulating intellectual processes and outcomes: A socio cognitive perspective. In David Yun Dai \& Robert J. Sternberg (Eds.). Motivation, emotion and cognition: Integrative perspective on intellectual functioning and development (pp. 333-418), London: Lawrence Erlbaum Associates.. 